\title{
PENGARUH PENAMBAHAN ASAM PADA JERAMI PADI DALAM MENINGKATKAN KAPASITAS SORPSI OIL SORBENT
}

\section{EFFECT OF ACID ADDITION ON RICE STRAW TO INCREASE SORBTION CAPACITY OF OIL SORBENT}

\author{
Nida Sopiah'1), Ummu Hanifah²), Nurhasni2) \\ (Diterima tanggal 09-06-2015; Disetujui tanggal 15-02-2016)
}

\begin{abstract}
ABSTRAK
Pengaruh Penambahan Asam pada Jerami Padi dalam Meningkatkan Kapasitas Sorpsi Oil Sorbent.

Gugus hidroksil yang terikat pada selulosa jerami dapat diaktivasi menggunakan asam karboksilat untuk memperpanjang rantai hidrokarbonnya sehingga dapat meningkatkan kapasitas sorpsi jerami padi dalam menyerap minyak mentah. Aktivasi kimia pada jerami padi dilakukan menggunakan asam asetat dan asam sitrat dengan variasi konsentrasi: 0,$25 ; 0,50 ; 0,75 ; 1,00 ; 1,25 ; 1,50 ; 1,75$ dan $2,00 \mathrm{~N}$, dilakukan pada suhu $120^{\circ} \mathrm{C}$ selama 30 menit. Uji kapasitas sorpsi dilakukan untuk mengetahui kemampuan menyerap minyak sedangkan karakterisasi dengan FTIR dilakukan untuk mengidentifikasi gugus fungsi yang terbentuk. Hasil penelitian menunjukkan bahwa konsentrasi asam berpengaruh terhadap kapasitas sorpsi yang dihasilkan. Kapasitas sorpsi optimal dari jerami padi yang diaktivasi asam asetat diperoleh pada konsentrasi 1,25 $\mathrm{N}$ sedangkan pada asam sitrat 1,75 N, dengan nilai kapasitas sorpsi masing-masing sebesar 11,14 g minyak/g sorben 11,18 g minyak/g sorben. Karakterisasi menggunakan FTIR menunjukkan adanya penambahan gugus fungsi karbonil $(C=O)$ pada bilangan gelombang $1637,63 \mathrm{~cm}^{-1}$ pada spectrum IR yang diaktivasi asetat, dan $1658 \mathrm{~cm}^{-1}$ pada spektrum IR yang diaktivasi sitrat. Hasil identifikasi gugus fungsi pada jerami padi sebelum dan sesudah diaktivasi asam mempunyai persamaan pada pita serapan yang dihasilkan yaitu munculnya serapan lebar pada bilangan gelombang sekitar $3300 \mathrm{~cm}^{-1}(-\mathrm{OH}$ group). $2900 \mathrm{~cm}^{-1}$ (C-H group). $1460-1470 \mathrm{~cm}^{-1}$ (- $\mathrm{CH}_{2}$ group), $1310 \mathrm{~cm}^{-1}$ (-CH group), dan pada bilangan gelombang sekitar $1050 \mathrm{~cm}^{-1}$ (C-O group).
\end{abstract}

Kata kunci :Aktivasi kimia, asam asetat, asam sitrat, minyak mentah, jerami padi

\begin{abstract}
Effect Acid Addition on Rice Straw to Increase Sorbtion Capacity of Oil Sorbent.

The cellulosic material attached by hydroxyl groups of rice straw can be chemically activated by carboxylic acid yields in longer-chain to increase the crude oil sorption capacity of rice straw as oil sorbent. Chemical activation of rice straw was done by acetic and citric acid in various concentrations of $0.25,0.50,0.75,1.00,1.25,1.50,1.75$, and $2.00 \mathrm{~N}$, respectively. It was carried out at $120^{\circ} \mathrm{C}$ for 30 minutes and then the sorption capacity was measured subsequently to know ability of oil sorption and characterized by FTIR to identify formed groups.

The results showed that the acid concentration effected the sorbtion capacity. The optimum sorption capacity of rice straw was obtained by acetic acid $1,25 \mathrm{~N}$ and citric acid $1.75 \mathrm{~N}$ activation. Optimum sorption capacity of crude oil at concentration of $11.14 \mathrm{~g}$ oil/g sorbent and $11.18 \mathrm{~g}$ oil/g sorbent respectively. Characterization of the IR spectrum using FTIR showed the additional carbonyl functional group $(C=O)$ at wave number $1637.63 \mathrm{~cm}^{-1}$ by acetate activation, and $1658 \mathrm{~cm}^{-1}$ by citric activation. The result of IR spectrum identification showed that before and after acid activation, the functional groups of rice straw had similarity to the absorption band, such as wide

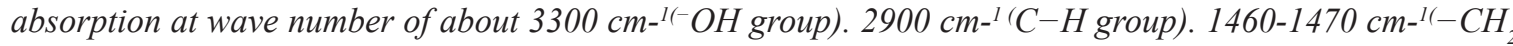
$1310 \mathrm{~cm}-1$ (-CH group), and the wave number at $1050 \mathrm{~cm}-{ }^{1}{ }^{2} \mathrm{C}-O$ group).
\end{abstract}

Keywords : Chemical activation, acetic acid, citric acid, crude oil , rice straw

\footnotetext{
1) Balai Teknologi Lingkungan Kedeputian Teknologi Pengembangan Sumberdaya Alam Badan Pengkajian dan Penerapan Teknlogi, Gedung 820 (Gedung GEOSTEK) Kawasan Puspiptek Serpong 15314 Tangerang Selatan Banten

2). Program Studi Kimia FST UIN Syarif Hidayatullah Jakarta
} 


\section{PENDAHULUAN}

Jerami padi merupakan salah satu potensi lokal yang sampai saat ini kajian pemanfaatannya masih terus dilakukan. Terlebih dengan adanya rencana pemerintah untuk meningkatkan areal persawahan dari 8,1 juta hektar lahan sawah tahun 2014 dan akan ditingkatkan menjadi 8,8 juta hektar lahan sawah pada tahun 2015 ${ }^{1)}$ menambah peluang untuk mengkaji potensi dari jerami padi untuk meningkatkan nilai tambah ekonomi.

Pemanfaatan jerami di masyarakat telah dilakukan di sektor pertanian dan peternakan sebagai pakan ternak, media tumbuh untuk produksi jamur merang, pupuk organik, dan sebagainya. Sedangkan yang bersifat kajian pemanfaatan jerami antara lain pemanfaatan jerami padi sebagai bahan baku pembuatan bioetanol'), untuk proses penjernihan air $^{3)}$, sorpsi logam ${ }^{4)}$,5), 6), pengurangan Free Fatty Acid (FFA) dan warna pada minyak jelantah ${ }^{7}$.

Kajian jerami padi sebagai oil sorbent ${ }^{8,9)}$ mulai dikembangkan karena jerami padi mempunyai kandungan selulosa $37,71 \%{ }^{10}$, yang mempunyai gugus hidroksil yang dapat dimodifikasi untuk meningkatkan sifat liofilitasnya.

Tujuan dari kajian ini adalah untuk meningkatkan nilai tambah dari limbah jerami padi dengan meningkatkan kapasitas sorpsi jerami padi sebagai oil sorbent dengan cara aktivasi kimia, diharapkan dengan adanya penambahan gugus hidrokarbon pada jerami padi yang diaktivasi asam karboksilat maka kapasitas sorpsinya akan meningkat.

Pada kajian ini limbah jerami padi diaktivasi menggunakan dua jenis asam organik yaitu asam sitrat dan asam asetat, adapun bahan uji yang digunakan dalam uji kapasitas sorpsi adalah minyak mentah.

Adanya penambahan gugus alkil dan karbonil pada jerami padi sebelum dan setelah proses aktivasi kimia selanjutnya diidentifikasi menggunakan Fourier Transform Infra Red (FTIR).

\section{BAHAN DAN METODE}

\section{Alat dan Bahan}

Peralatan yang digunakan dalam penelitian ini adalah ayakan kasar, kertas saring, $\mathrm{pH}$ meter WTW pH 720 InoLab, timbangan analitik Sartorius CP2245, oven Memmert UN55, penangas, Furnace Thermolyne Type 47900, Fourier Transform Infrared (FTIR) Shimadzu IR 21, kain nilon (10x10 cm) dan tali $(15 \mathrm{~cm})$, dan peralatan gelas lainnya.

Bahan yang digunakan dalam penelitian ini adalah jerami padi yang berasal dari Desa Dangdang Cisauk Tangerang, Minyak mentah yang berasal dari Cepu Jawa Tengah, asam asetat, aquadest, buffer asetat pH 4 dan 7 .

\section{Prosedur Kerja}

\section{Penyiapan Bahan Uji}

Jerami padi dikeringkan dengan cara dianginanginkan di ruang terbuka, sampai diperoleh kadar air lebih kecil dari 10\%. kemudian dilakukan penggilingan selanjutnya diayak dengan ayakan kasar. Setelah itu, dimasukkan dalam oven dengan suhu $105^{\circ} \mathrm{C}$ sampai diperoleh berat konstan dan disimpan dalam desikator.

\section{Aktivasi Kimia Jerami padi dengan Asam}

Pada penelitian ini dilakukan uji aktivasi kimia pada jerami padi sebagai bahan uji dengan cara ditimbang masing-masing sebanyak 10 
g dan dimasukkan dalam labu Erlenmeyer. Kemudian ditambahkan $40 \mathrm{ml}$ asam asetat pada labu yang satu dan yang lainnya asam sitrat dengan variasi konsentrasi 0,$25 ; 0,50$; 0,$75 ; 1,00 ; 1,25 ; 1,50 ; 1,75$ dan $2,00 \mathrm{~N}$. Masing-masing campuran tersebut diaduk kemudian dipanaskan menggunakan penangas pada suhu $120^{\circ} \mathrm{C}$ selama 30 menit, kemudian disaring dan residunya dioven pada suhu $50^{\circ} \mathrm{C}$ selama 24 jam. Selanjutnya residu dicuci dengan aquadest sampai diperoleh $\mathrm{pH}$ netral. Pengukuran $\mathrm{pH}$ dilakukan menggunakan $\mathrm{pH}$ meter yang sebelumnya telah dikalibrasi terlebih dahulu.

Masing-masing jerami padi yang sudah diaktivasi (sorben) dimasukan dalam dalam oven untuk dikeringkan pada suhu $105^{\circ} \mathrm{C}$ sampai diperoleh berat konstan.Selanjutnya sorben yang telah diaktivasi dimasukkan ke dalam desikator untuk selanjutnya dilakukan pengujian kapasitas sorpsi terhadap minyak mentah.

\section{Pengujian Kapasitas sorpsi Jerami Padi Teraktivasi Terhadap Minyak Mentah}

Jerami padi yang telah diaktivasi masingmasing ditimbang $1,00 \pm 0,50 \mathrm{~g}$ lalu dimasukkan ke dalam selongsong kain nilon yang telah ditimbang dan diikat dengan tali. Kemudian selongsong tersebut dimasukkan dalam beaker glass $500 \mathrm{ml}$ yang berisi minyak mentah 300 ml selama 15 menit, lalu ditiriskan 15 menit. Setelah itu ditimbang berat akhir dan dihitung nilai kapasitas sorpsi minyak (Q).

Kapasitas Sorpsi Minyak Mentah oleh Jerami Padi:

$$
\mathrm{Q}=\frac{\mathrm{W}_{\text {total }}-\left(\mathrm{W}_{\text {kain }+ \text { minyak }}\right)-\mathrm{W}_{\text {sorben }}}{\mathrm{W}_{\text {sorben }}}
$$

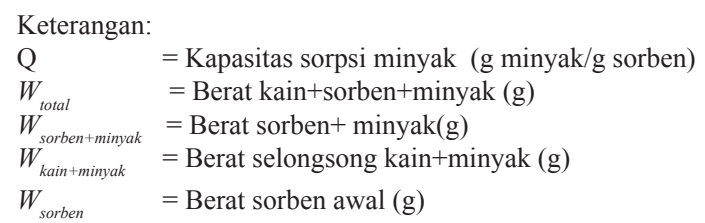

\section{Karakterisasi dengan Fourier Transform Infrared(FTIR)}

Bahan uji dan senyawa $\mathrm{KBr}(1: 100)$ dicampurkan dalam mortar, selanjutnya digerus sampai homogen. Kemudian dibuat pellet dengan memasukkan ke dalam alat press. Pellet yang sudah jadi diletakkan dalam sampel holder. Selanjutnya dilakukan pengukuran dengan FTIR dan diamati spektrum yang terbentuk.

\section{HASIL DAN PEMBAHASAN}

\section{Pengaruh Aktivasi Kimia terhadap} Kapasitas Sorpsi Minyak Mentah

Proses sorpsi suatu bahan uji (sorben) terhadap sorbat sangat ditentukan dari seberapa besar kemampuan sorben tersebut dalam melakukan penyerapan. Komposisi utama jerami padi terdiri atas selulosa $37,71 \%{ }^{9}$ ). memungkinkan untuk dilakukan modifikasi pada gugus fungsi hidroksilnya

$(-\mathrm{OH})$ dengan cara mengaktivasi jerami padi tersebut menggunakan asam karboksilat. Proses aktivasi kimia menggunakan asam asetat dan sitrat dengan bantuan pemanasan dapat memperpanjang gugus hidrokarbon dan gugus karbonil yang mampu meningkatkan sifat hidrofobisitas jerami padi sehingga dapat meningkatkan kemampuan dalam menyerap minyak (oil sorbent).

Asam sitrat merupakan asam organik lemah yang mempunyai tiga gugus asam karboksilat (trikarboksilat) dengan tiga buah nilai $\mathrm{pKa}$ 
yaitu 3,$15 ; 4,77$ dan $\mathrm{pKa} 3=6,40$

Sedangkan Asam asetat merupakan asam organik lemah yang mempunyai satu gugus asam karboksilat (monokarboksilat) dengan nilai pKa yaitu 4,76 .

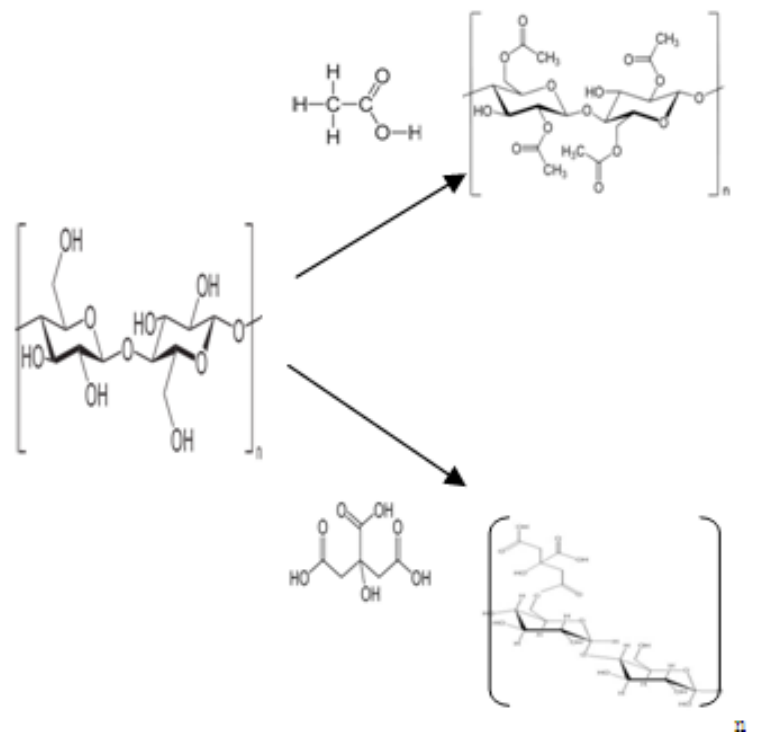

Gambar 1. Reaksi asam asetat dan asam sitrat dengan selulosa

Berdasarkan struktur kimianya, kedua asam tersebut dimungkinkan untuk bereaksi dengan selulosa, karena asam asetat dan sitrat mempunyai gugus karboksilat yang dapat bereaksi dengan gugus hidroksil yang terikat pada selulosa. Asam asetat mempunyai struktur kimia yang lebih sederhana daripada asam sitrat sehingga faktor sterik ruang pada asam sitrat untuk berikatan dengan selulosa mempengaruhi kekuatan ikatan yang terbentuk antara selulosa dengan asam sitrat.

Data kajian menunjukkan bahwa jerami padi sebelum dilakukan aktivasi kimia mempunyai kapasitas sorpsi sebesar 4,62 minyak/g sorben dan mengalami peningkatan secara signifikan setelah dilakukan aktivasi menggunakan asam asetat maupun sitrat. Aktivasi kimia menggunakan kedua asam tersebut mampu meningkatkan kapasitas sorpsi sebesar tiga kali lebih besar dibanding kontrol. Adapun konsentrasi optimum pada asetat terdapat pada konsentrasi $1,25 \mathrm{~N}$ dan pada asam sitrat optimum pada konsentrasi 1,75 N. dengan nilai kapasitas sorpsi masing-masing adalah $11,14 \mathrm{~g}$ minyak/g sorben $11,18 \mathrm{~g}$ minyak/g sorben.

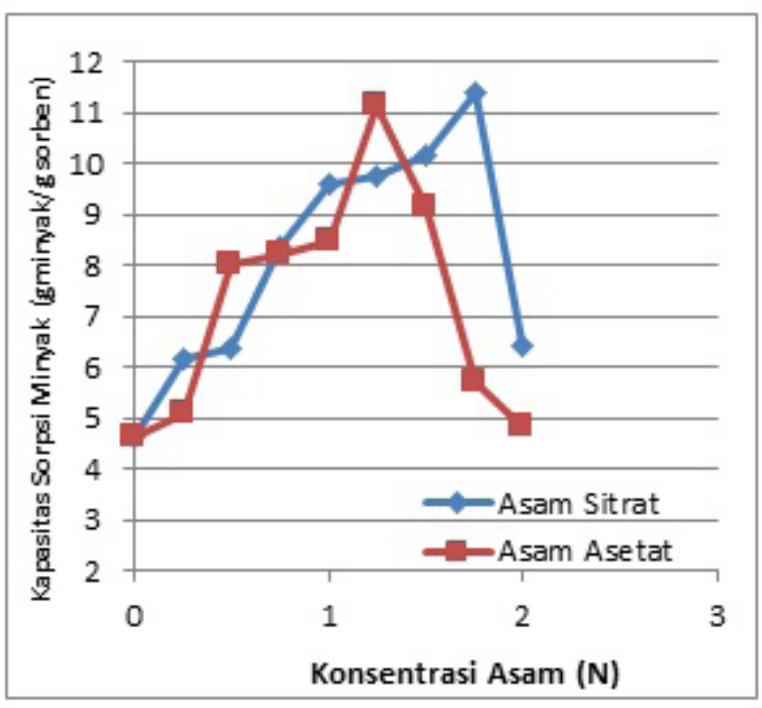

Gambar 2. Kapasitas sorpsi dari jerami padi yang diaktivasi oleh asam asetat dan asam sitrat

Setelah dicapai konsentrasi optimum pada asam asetat $1,25 \mathrm{~N}$, kapasitas sorpsi mengalami penurunan pada asam asetat $1,50 \mathrm{~N}$ menjadi 9,15 , kemudian berturut-turun menjadi 5,67 dan 4,8 g minyak/g sorben pada konsentrasi asam asetat 1,75 dan 2,00N.

Sedangkan pada jerami padi yang diaktivasi asam sitrat mengalami penurunan kapasitas sorpsinya pada $2,00 \mathrm{~N}$, dengan nilai kapasitas sorpsinya sebesar $6,40 \mathrm{~g}$ minyak/g sorben. Penurunan kapasitas sorpsi ini terjadi diduga disebabkan terjadinya hidrolisis ikatan glikosidik $\beta-1,4$ akan terjadi jika dilakukan pemanasan dengan asam kuat dan konsentrasi tinggi ${ }^{11)}$ dan terjadinya desorpsi yang disebabkan oleh terhalangnya pori-pori 
jerami padi oleh keberadaan faktor sterik sehingga minyak yang dapat menempati pori tersebut hanya sedikit dan hanya melekat pada permukaan pori yang bersifat lipofil saja ${ }^{(12)}$.

\section{Karakterisasi denganFourier Transform Infra Red (FTIR)}

Spektrofotometer FTIR merupakan salah satu alat yang dapat digunakan untuk identifikasi senyawa, khususnya senyawa organik, baik secara kualitatif maupun kuantitatif.Analisis dilakukan dengan melihat bentuk spektrumnya yaitu dengan melihat puncak-puncak spesifik yang menunjukan jenis gugus fungsional yang dimiliki oleh senyawa tersebut ${ }^{(13)}$.

Karakterisasi dengan FTIR dilakukan untuk mengidentifikasi gugus fungsi yang terdapat pada jerami padi sebelum dilakukan aktivasi dan setelah diaktivasi dengan asam asetat maupun asam sitrat. Daerah serapan gelombang setiap gugus fungsi yang muncul pada spektrum.
Interpretasi senyawa dilakukan mengacu kepada tabel berikut ini :

Dari hasil pengukuran menggunakan FTIR diperoleh spektrum IR pada jerami padi sebelum diaktivasi tampak seperti gambar berikut ini :

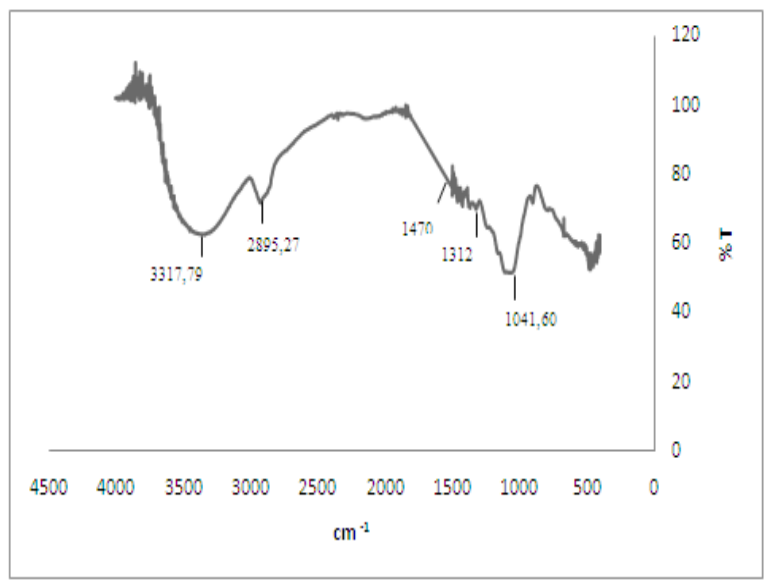

Gambar 3.Spektrum FTIR jerami padi tanpa aktivasi (kontrol).

Dari gambar spektrum diatas dapat diketahui bahwa di dalam jerami padi tanpa aktivasi terdapat bilangan gelombang $3317,79 \mathrm{~cm}^{-1}$

Tabel 1. Daerah Serapan Gelombang Beberapa Gugus Fungsi (14).

\begin{tabular}{ccc}
\hline Daerah Serapan $\left(\mathrm{cm}^{-1}\right)$ & Gugus Fungsi & Nama gugus fungsi \\
\hline $2850-2960$ & $\mathrm{C}-\mathrm{H}$ & Alkana \\
$1350-1470$ & & Alkena \\
$3020-3080$ & $\mathrm{C}-\mathrm{H}$ & Aromatik \\
$675-870$ & & Alkuna \\
$3000-3100$ & $\mathrm{C}-\mathrm{H}$ & Alkena \\
$675-870$ & $\mathrm{C}-\mathrm{H}$ & Aromatik (cincin) \\
3300 & $\mathrm{C}=\mathrm{C}$ & $\mathrm{C}=\mathrm{C}$ \\
$1640-1680$ & $\mathrm{C}=\mathrm{O}$ & Alkohol, eter, asam karboksilat, ester \\
$1500-1600$ & $\mathrm{O}-\mathrm{H}$ & Alkohol, fenol (monomer) \\
$1690-1760$ & $\mathrm{O}-\mathrm{H}$ & Alkohol fenol (ikatan hidrogen) \\
$3610-3640$ & $\mathrm{O}-\mathrm{H}$ & Asam karboksilat \\
$2000-3600$ & $\mathrm{~N}-\mathrm{H}$ & Amina \\
$3000-3600$ & $\mathrm{C}-\mathrm{N}$ & Amina \\
$3310-3350$ & $-\mathrm{NO}$ & Nitro \\
$1180-1360$ & & \\
$1515-1560$ & & \\
$1345-1385$ & &
\end{tabular}


yang menunjukkan adanya gugus $-\mathrm{OH}$. Pada bilangan gelombang $2895,27 \mathrm{~cm}^{-1}$ menunjukkan adanya gugus $\mathrm{C}-\mathrm{H}$, pada bilangan gelombang $1470 \mathrm{~cm}^{-1}$ menunjukkan adanya gugus $\mathrm{CH}_{2}$, pada bilangan gelombang $1312 \mathrm{~cm}^{-1}$ menunjukkan adanya gugus $\mathrm{CH}$, dan pada bilangan gelombang 1041,60 menunjukkan adanya gugus $\mathrm{C}-\mathrm{O}$.

Hasil interpretasi gugus fungsi pada jerami padi yang diaktivasi asam asetat $1,25 \mathrm{~N}$ (Gambar 3) diperolehnya puncak serapan pada bilangan gelombang $3326,38 \mathrm{~cm}^{-1}$ yang menunjukkan vibrasi ulur gugus $-\mathrm{OH}$ dari asam karboksilat, diperkuat dengan adanya vibrasi ulur gugus $\mathrm{C}=\mathrm{O}$ dari asam karboksilat yang muncul pada serapan 1637,63 $\mathrm{cm}^{-1}$. Serapan ada bilangan gelombang 2907,81 $\mathrm{cm}^{-1}$ menunjukkan adanya vibrasi ulur gugus C-H dari alkana, pada bilangan gelombang menunjukkan adanya gugus $\mathrm{C}=\mathrm{O}$. Serapan pada bilangan gelombang sekitar 1463,06 cm-1 menunjukkan adanya vibrasi tekuk gugus $\mathrm{CH}_{2}$ metilen Serapan pada bilangan gelombang $1076,32 \mathrm{~cm}^{-1}$ menunjukkan vibrasi ulur gugus C-O.

Hasil interpretasi pada jerami padi yang diaktivasi asam sitrat 1,75 $\mathrm{N}$ terdapat serapan lebar pada bilangan gelombang $3391 \mathrm{~cm}^{-1}$ yang menunjukkan adanya vibrasi ulur gugus $-\mathrm{OH}$ dari asam karboksilat, diperkuat dengan adanya vibrasi ulur gugus $\mathrm{C}=\mathrm{O}$ dari asam karboksilat yang muncul pada serapan $1658 \mathrm{~cm}^{-1}$. Serapan pada bilangan gelombang $2936 \mathrm{~cm}^{-1}$ menunjukkan adanya vibrasi ulur gugus $\mathrm{C}-\mathrm{H}$ dari alkana. Serapan pada bilangan gelombang sekitar $1465 \mathrm{~cm}^{-1}$ menunjukkan adanya vibrasi tekuk gugus $\mathrm{CH}_{2}$ metilen Gambar 6 dibawah ini menunjukkan spektrum FTIR jerami padi yang telah diaktivasi asam sitrat $1,75 \mathrm{~N}$.

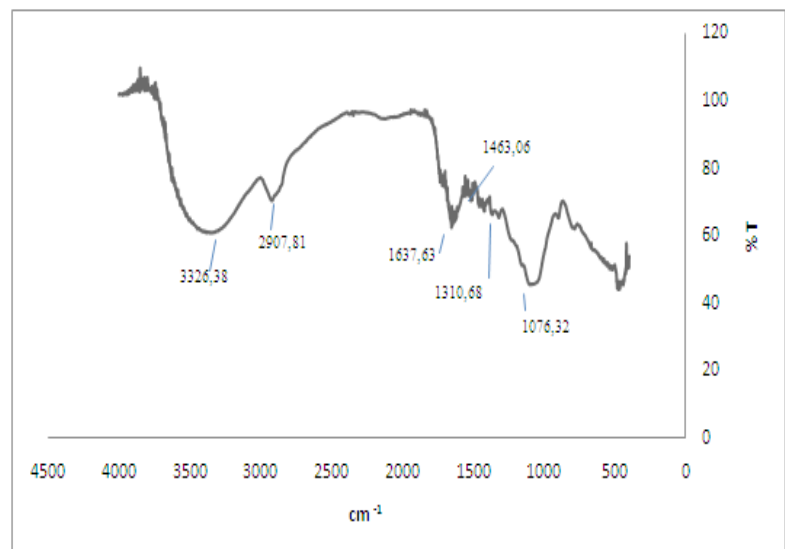

Gambar 3. Spektrum FTIR Jerami Padi yang Diaktivasi Asam Asetat $1,25 \mathrm{~N}$

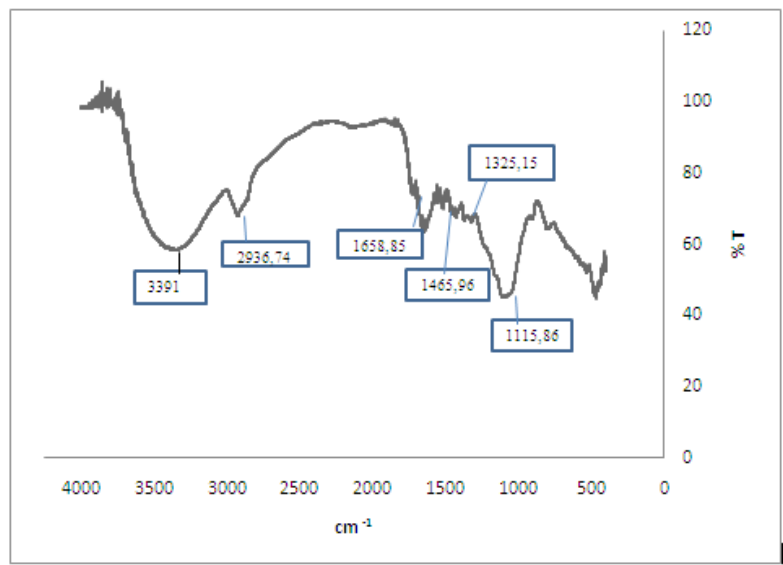

Gambar 4. Spektrum FTIR Jerami Padi yang diaktivasi Asam Sitrat $1,75 \mathrm{~N}$

Hasil identifikasi gugus fungsi pada jerami padi sebelum dan sesudah diaktivasi asam asetat maupun sitrat mempunyai persamaan pada pita serapan yang dihasilkan yaitu munculnya serapan lebar pada bilangan gelombang sekitar $3300 \mathrm{~cm}^{-1}(-\mathrm{OH})$, serapan pada sekitar bilangan gelombang $2900 \mathrm{~cm}^{-1}$ (C-H), serapan pada bilangan gelombang sekitar 1460-1470 $\mathrm{cm}^{-1}\left(-\mathrm{CH}_{2}\right)$, serapan pada bilangan gelombang sekitar $1310 \mathrm{~cm}^{-1}(-\mathrm{CH})$ dan pada bilangan gelombang sekitar 1050 $\mathrm{cm}^{-1}(\mathrm{C}-\mathrm{O})$.

Adapun yang membedakan dari kedua spektrum tersebut adalah pada jerami padi yang tidak diaktivasi asam asetat maupun sitrat 
pada bilangan gelombang sekitar 1600-1700 $\mathrm{cm}^{-1}$ tidak muncul serapan pita pada daerah tersebut, sedangkan setelah proses aktivasi menggunakan asam asetat 1,25 $\mathrm{N}$ maupun asam sitrat $1,75 \mathrm{~N}$, pada spektrum muncul pita serapan pada bilangan gelombang sekitar 1650 $\mathrm{cm}^{-1}$ menunjukkan adanya regangan gugus karbonil $(\mathrm{C}=\mathrm{O})$.

\section{KESIMPULAN}

Kapasitas sorpsi dari jerami dapat ditingkatkan dengan melakukan aktivasi kimia dengan asam asetat maupun asam sitrat pada suhu $120^{\circ} \mathrm{C}$ selama 30 menit mampu meningkatkan kapasitas sorpsi dari 4,62g minyak/g sorben menjadi $11,14 \mathrm{~g}$ minyak/g sorben aktivasi menggunakan asam asetat $1,25 \mathrm{~N}$ dan 11,18 g minyak/g sorben menggunakan asam sitrat 1,75 N. Meningkatnya kemampuan sorpsi dapat dapat diidentifikasi dari spektrum FTIR, dimana terbentuk serapan $\mathrm{C}=\mathrm{O}$ pada bilangan gelombang $1637,63 \mathrm{~cm}^{-1}$

\section{DAFTAR PUSTAKA}

(1) Luas Lahan Pertanian Naik 700 Ribu Hektar. 21 April 2015 17:29 WIB,Diakses 29 Juni 2015 http:// bisniskeuangan.kompas.com/ $\mathrm{read} / 2015 / 04 / 21 / 172902726 /$ Luas. Lahan.Pertanian.Naik.700.Ribu. Hektar

(2) Kim S, Dale BE. Global Potential Bioethanol Production from Wasted Crops and Crop Residues. Biomass and Bioenergy. 2004. 26:361-375

(3) Esti, Sahar H. Pengelolaan Air dan Sanitasi. Jakarta. Kantor Deputi Menegristek Bidang Pendayagunaan dan Pemasyarakatan Ilmu Pengetahuan dan Teknologi. 2000
(4) Safrianti I, Wahyuni N, Zaharah TA. Sorpsi Timbal (II) oleh Selulosa Limbah Jerami Padi Teraktivasi Asam Nitrat: Pengaruh $\mathrm{pH}$ dan Waktu Kontak. Jurnal JKK. 2012.1(1):1-7

(5) Fatoni AH, Hindryawati N, Sari $\mathrm{N}$, Pengaruh $\mathrm{pH}$ terhadap Sorpsi Ion Logam Kadmium (II) oleh Sorben Jerami Padi. Jurnal Kimia Mulawarman. 2010. 7(5): 59-61

(6) Yanuar HM, Sandi D, Manalu JV. Sorpsi ion $\mathrm{Pb}^{2+}$ dalam Air dengan Jerami Padi. Jurnal Percikan. 2009. 100: $67-74$

(7) Pakpahan JP, Tambunan T, Harimby A, Ritonga MY. Pengurangan FFA dan Warna dari Minyak Jelantah dengan Sorben Serabut Kelapa dan Jerami Jurnal Teknik Kimia USU. 2013. 2(1): 31-36

(8) Sopiah N, Adi M, Widya K. Pemanfaatan Serbuk Gergaji Kayu Sengon (Albizia chinensis) sebagai oil sorbent dengan kombinasi aktivasi fisik. Pros. Semnas Pengelolaan Sumberdaya Alam dan Lingkungan : Pembangunan Berkelanjut- an dalam Perspektif Ketahanan Energi, Pengelolaan Lingkungan dan Pengelola- an Bencana. UNDIP. Semarang. 2014 : 314 - 320

(10) Sopiah N. Aktivasi Jerami Padi sebagai Oil Sorbent Menggunakan Asam Asetat. Jurnal Teknologi Lingkungan. 2015. 16(1): 27-30

(11) Dewi. Hidrolisis Limbah Hasil Pertanian secara Enzimatik. Jurnal Akta Agrosia. 2002. 5(2): 67-71

(12) Belitz HD, Grosch W. Food Chemistry. Heidelberg. Springer-Verlag Berlin. 1987 
(13) Barlianti V, Wiloso EI. Potensi Pemanfaatan Lignoselulosa dan Coir Dust sebagai Penyerap Tumpahan Minyak pada Air. Majalah Ilmiah. Serpong. 2008. 18. 43(2) : 101-106.

(14) Kristianingrum S. Hand out Instrumen IR. Diakses 30 September 2014. staff.uny.ac.id/.../Susila\%20 Kristianingrum..../ Hand out Instrumen IR
(15) Supratman U. Elusidasi Struktur Senyawa Organik. Widya Padjadjaran. Bandung. 2010

(16) Lambert JB. Introduction to Organic Spectroscopy. MacMillan Publ. New York. 1987 